\title{
Comparison of Continuous Strip Casting with Conventional Technology
}

\author{
Nikolai ZAPUSKALOV \\ Consulting,6/29 Halstead st, Coorparoo, Qld 4151, Australia. E-mail: zapuskalov@inbox.ru
}

(Receiverd on October 28, 2002; accepted in final form on February 3, 2003)

\begin{abstract}
Increased competition and the need to decrease steel product prices has combined with other factors such as growing salaries, increasing cost for electricity and raw materials to apply pressure to both mini and integrated mills. To compete in the future market and to maintain market share, both mills will need to use new efficient technologies capable of supplying steel strip products of high quality at low cost. Large investments in the development of strip casting process by the main world steel produces and plantmakers have already occurred due to its huge potential to substantially reduce the investment cost of steel strip production. Open literature on the continuous casting has been reviewed, with emphasis on strip casting of steel as new generation of continuous casting technology and has covered the following topics: current trends in production of steel strip; advantages of strip produced direct from the melt; strip casting process; strip quality; commercial strip casters and expenditure on research and development of the strip casting process.
\end{abstract}

KEY WORDS: continuous casting; strip casting; twin-roll casting, steel; near net shape casting; mini mill; micro mill; review.

\section{Introduction}

The idea of strip casting belongs to $\mathrm{H}$. Bessemer, a wellknown steelmaker who started from simple tests using two hardened rolls and a small nine kilogram-capacity crucible, ${ }^{1)}$ as shown in Fig. 1(a). A little later, in 1865 he obtained a patent for the strip casting of steel and iron ${ }^{2)}$ as shown in Fig. 1(b).

The first commercial applications of the strip casting process involved the production of small amounts of materials with relatively simple casting properties such as cast iron. In 1934 to 1950 in the USSR this technique was successfully applied for casting iron sheets intended for roofing. ${ }^{3-5)}$ In 1950 J. Hunter and W. Lauener started to cast strips from aluminum and its alloys. ${ }^{6,7)}$

The thermal-physical properties of steel make the casting of steel strip a complicated task and large production runs are required to make the process profitable. ${ }^{8)}$ That is why, despite enormous efforts by researchers, the casting of steel strip has only recently become feasible. ${ }^{9-12)}$

Literature based on business, scientific and research publications on the continuous casting has been reviewed, with emphasis on strip casting of steel as new generation of continuous casting technology and covers the following topics: current trends in production of steel strip; advantages of

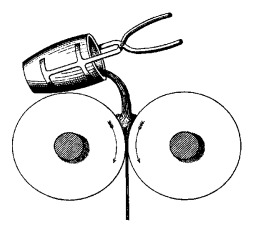

a.

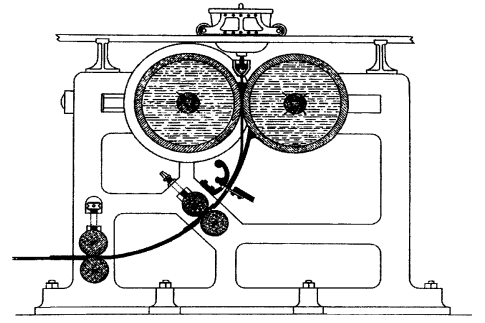

b.
Fig. 1. (a) Sketch of strip caster was drawn by H. Bessemer in $1856^{1)}$ and (b) his strip caster patented in $1865 .^{2)}$ strip produced direct from the liquid steel; strip casting process; strip quality; commercial strip casters and expenditure on research and development of the strip casting process.

The definition of thin strip in this review is $0.1-5.0 \mathrm{~mm}$ thick. The technology of casting thicker strip ${ }^{13-15)}$ as well as thinner strip (foils) with an "amorphous" and microcrystalline structure, ${ }^{16)}$ is not the aim of this review. The review does not include a comprehensive review of patents.

\section{Current Trends in Production of Steel Strip}

Nowadays steel strip is made at two types of mills, differing not only in size but also in production "philosophy" ${ }^{17)}$

The first type of the mills is the integrated mill with usually 3-5 million ton per year production capacity. ${ }^{18)}$ Such mills are oriented to large consumers demanding high steel quality as well as large tonnage. Location of the integrated mills is not bound with their consumers geographically. The technological basis of the integrated mills is the continuous casting of slab with thickness $\sim 200 \mathrm{~mm}^{19,20)}$ as shown in Fig. 2. For obtaining strip with thickness of $3-20 \mathrm{~mm}$, the slab has to run through a large number of processing steps. Numerous operations of heating and rolling can rectify some defects inherent in the cast structure and produce high-quality strip. But this production route has high associated costs due to the powerful rolling and heating equipment required and the labor intensive nature of the process. ${ }^{22}$ This type of mill is profitable if the production tonnage is several million ton per annum. ${ }^{8,23)}$

The second type of mill includes the mini-mills with production capacity of $0.5-2.0$ million ton per annum. ${ }^{18,24)}$ Such mills are located near the customers, who are not in need of large tonnage and high steel surface quality requirements. The technological basis of the mini mill is the continuous casting of a thin slab with a thickness of approximately $50 \mathrm{~mm}^{19,25)}$ as illustrated in Fig. 2. Thin slab casting reduces production costs by eliminating several pro- 
cessing steps such as hot rolling and intermediate heating. ${ }^{22,26,27)}$ At such a mill the production process is compact, easy to control and does not require large investment in either equipment and personnel. ${ }^{26,27)}$ However, along with a shorter processing route, the possibilities of correcting potential defects of the cast slab are also decreased. That is why only steel of a certain chemical composition is suitable for the casting of a thin slab. ${ }^{28}$ ) The mini mill is found to be the most profitable when steel scrap can be sourced from within a $200-\mathrm{km}$ region around the mill and products can be sold in a vicinity of up to $500-\mathrm{km}$ radius. ${ }^{29,30)}$ The mini mill process is most suited to the production of ordinary grades of steel typically medium and low carbon steels and HSLA grades. ${ }^{31)}$ The first mini-mill was built in the USA by Nucor and SMS in 1989. ${ }^{32}$

Year by year, the share of mini mills is growing, ${ }^{33)}$ but in the near future this growth may slow, due to the following reasons.

Currently more than half of the metallurgical equipment operating at large steel manufactures throughout the world has been in use for over a quarter of a century ${ }^{34)}$ see Table 1. This equipment should be replaced in the near future. For companies currently running integrated mills the modernization of existing equipment and processes allows more rapid cost recovery then investing in the construction of

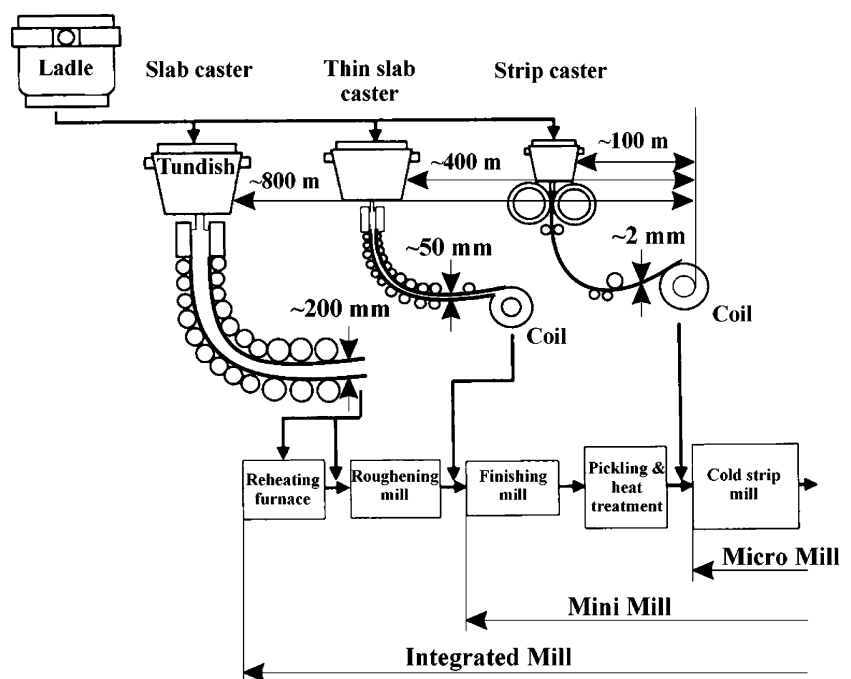

Fig. 2. Strip manufacturing processes. (Update from Ref. 21).) new mini mills ${ }^{27)}$ (Fig. 3). This may lead to a partial loss of the potential market for mini mills.

The other reason concerns the ever-growing application of electronics in the automotive industry ${ }^{35)}$ and surface coating material for steel products, ${ }^{36}$ which contaminate steel scrap with deleterious impurities, such as copper and tin that are difficult to remove ${ }^{36,37)}$ (Fig. 4). The price of steel scrap is estimated to increase by $\$ 8$ per ton for each reduction of $0.1 \%$ of residual impurities. ${ }^{38)}$ Therefore, the price for high quality scrap is likely to rise in the future. ${ }^{38,39)}$ Since the mini mills product cost strongly depends on the steel scrap price ${ }^{18,40)}$ as illustrated in Table 2, this is likely to further retard investment in mini mills. Each of these reasons is motivating the development of a new generation of mini mills.

The owners of integrated mills are also investing heavily in the development of new technology. ${ }^{18,41)}$ Lately, the structure of steel demand has undergone serious changes. The competitiveness of steel producers depends a lot on product cost and the ability to make products satisfying specific customer demands. ${ }^{42)}$ In the conditions of largescale production it is difficult to offer a wide range of steels designed for individual and small consumers. The current steel market demands a wide variety of steel grades with different properties, surface appearance and geometry. This is particularly true for stainless grades. ${ }^{43)}$ Additionally, today's stainless steel producers are not able to offer their products on a long-term basis and at fixed prices because of a strong dependence on the prices of alloying elements such as nickel and chrome, which regularly fluctuate. ${ }^{41,44)}$ To satisfy market demands, integrated steel mills require technology advances that will allow the low-cost production of a diverse range of small, high-quality lots. ${ }^{10,41)}$

Additionally, increasing substitution of light alloys in the packaging, automotive and construction industries as alternative materials to steel have applied pressure to the steel producers to reduce production costs to maintain market share. ${ }^{18,35,45)}$

Thus increased competition and the need to decrease steel product prices has combined with other factors such as growing salaries, increasing cost of electricity and raw materials to apply pressure to both mini and integrated mills. ${ }^{17,46-48)}$ To compete in the future market, both mills will need to use efficient technologies capable of supplying

Table 1. Crude steel capacity, utilization, age and replacement potential of existing steel production facilities. ${ }^{34)}$

\begin{tabular}{|l|c|c|c|c|}
\hline \multicolumn{1}{|c|}{ Region } & $\begin{array}{l}\text { Crude steel capacity, } \\
\text { million ton per annum }\end{array}$ & $\begin{array}{c}\text { Rate of plant } \\
\text { utilization, } \\
\text { \% }\end{array}$ & $\begin{array}{c}\text { Age steel production } \\
\text { structure<1975, \% }\end{array}$ & $\begin{array}{c}\text { Replacement } \\
\text { potential, } \\
\text { million ton per } \\
\text { annum }\end{array}$ \\
\hline Western Europe & 212 & 81.5 & 58.1 & 4.8 \\
\hline Central/Eastern Europe & 45 & 64.3 & 75.2 & 1.3 \\
\hline CIS and Baltic States & 137 & 57.0 & 77.5 & 4.2 \\
\hline Near/Middle East, North Africa & 14 & 85.1 & 14.6 & 0.8 \\
\hline Other Africa & 13 & 63.4 & 63.1 & 0.3 \\
\hline India & 29 & 85.0 & 45 & 0.5 \\
\hline Republic of China & 124 & 87.7 & 20 & 1.0 \\
\hline Republic of Korea & 56 & 104.7 & 15 & 0.3 \\
\hline Japan & 132 & 79.0 & 67 & 3.4 \\
\hline Australia, New Zealand & 10 & 97.8 & 68 & 0.2 \\
\hline S/E-Asia & 18 & 56.2 & 17.7 & 0.1 \\
\hline North America & 149 & 86.5 & 62.4 & 3.6 \\
\hline Latin America & 46 & 77.0 & 31.5 & 0.6 \\
\hline World total & $\mathbf{9 8 5}$ & $\mathbf{7 9 . 2}$ & $\mathbf{5 3 . 4}$ & $\mathbf{2 1 . 1}$ \\
\hline
\end{tabular}


Existing integrated mill

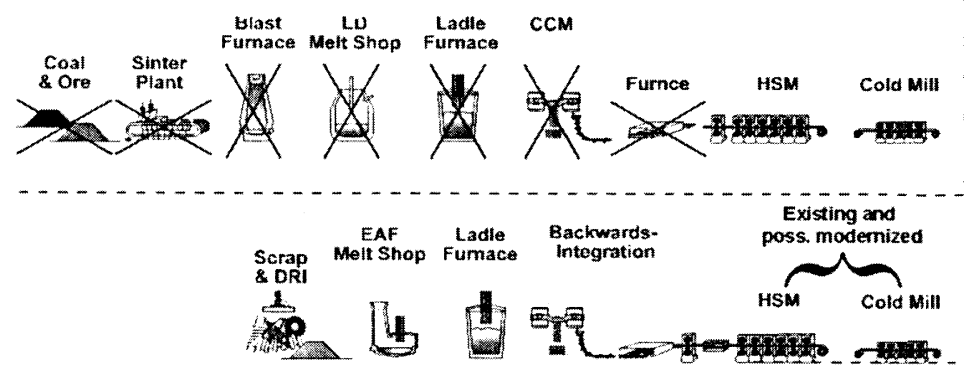

Modernized integrated mill by backwards integration

a.

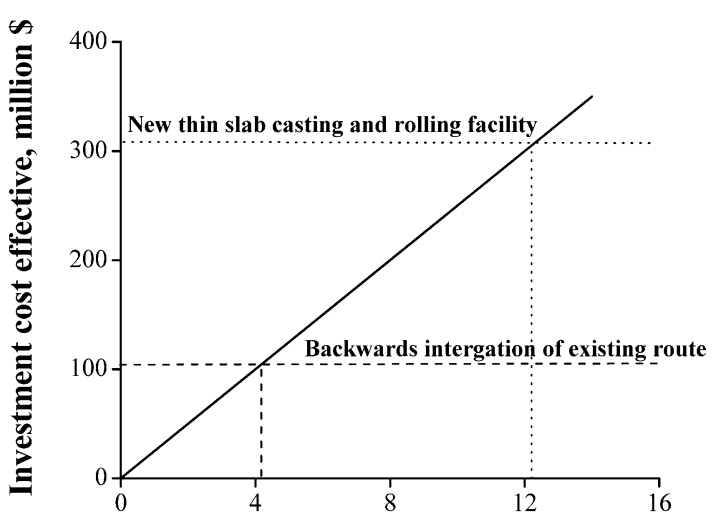

Return on investment in years

Fig. 3. Backward integration using existing hot and cold rolling of integrated mill: (a) schematic view; (b) comparison of return on investment of a new thin slab casting and rolling facility and backwards integration of an existing conventional rout of integrated mill. Where Investment cost effective $=$ Investment $\cos \mathrm{t}-$ Cost savings for closing of slab storage, Number of years before return on investment $=$ Investment cost effective $/($ Cash cost savings relative + Sales bonus for improved product) ${ }^{27)}$
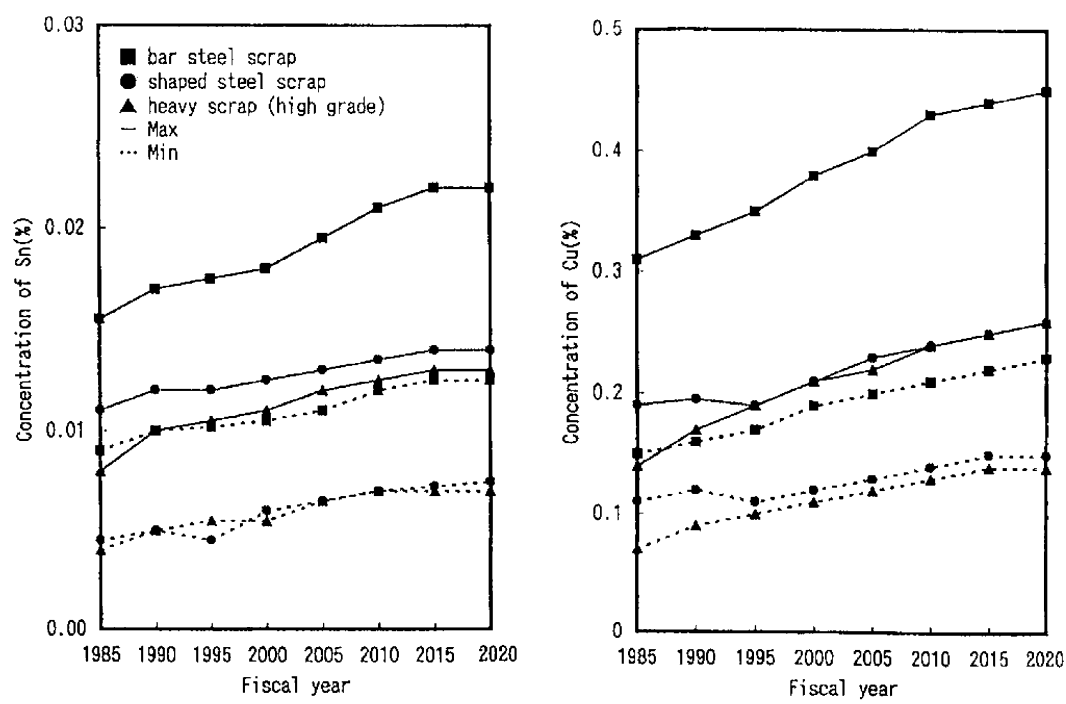

Fig. 4. Prediction for development of tin and copper content of scrap in futures. ${ }^{36)}$

Table 2. The effect of scrap price on the cost of producing liquid steel (per ton of liquid steel). ${ }^{18)}$

\begin{tabular}{|l|c|c|c|c|}
\hline & \multicolumn{2}{|c|}{ Mini Mill } & \multicolumn{2}{c|}{ Integrated mill } \\
\hline $\begin{array}{c}\text { Scrap price per } \\
\text { ton }\end{array}$ & $\mathbf{\$ 1 0 0}$ & $\mathbf{\$ 1 5 0}$ & $\mathbf{\$ 1 5 0}$ \\
\hline Scrap & $\mathbf{1 0 0}$ & 150 & 25 & 37 \\
\hline Ore & - & - & 41 & 41 \\
\hline Coke/Coal & - & 20 & 53 & 53 \\
\hline Electricity & 20 & 10 & 20 & 20 \\
\hline Labor & 10 & 28 & 30 & 30 \\
\hline Other & 28 & 25 & 65 & $\mathbf{\$ 2 3 1}$ \\
\hline Capital & 25 & $\mathbf{\$ 2 4 8}$ & $\mathbf{\$ 2 1 9}$ & 5 \\
\hline Total cost & $\mathbf{\$ 1 9 3}$ & & & \\
\hline
\end{tabular}


steel strip products of high quality at low cost.

\section{Advantages of Strip Produced Directly from the Melt}

The strip production costs increase steeply as the final product thickness decreases and the initial slab thickness increases. ${ }^{49)}$ In the processing of a thin slab, the production costs start to increase dramatically if rolling a strip of thickness below $1.2 \mathrm{~mm}^{50)}$ However the strip casting process allows strip to be produced at a thickness less than $1.8 \mathrm{~mm}$ at a stable cost. ${ }^{50,51)}$

Traditional casting machines with oscillation moulds are unsuitable for the casting of thin steel strip. As the thin strip solidifies rapidly ${ }^{52}$ it should be cast at higher speed, however as the speed increases, friction on the mould surface increases greatly (Fig. 5) and defects like surface cracks may form. ${ }^{53-56)}$

In the traditional casting methods the techniques of mould oscillation and lubrication with slag at the mould/slab interface are used to reduce friction. These techniques cannot be used for strip casting as oscillation results in marks on the surface and interactions with the slag may leave defects of a size comparable to the strip thickness. $^{56)}$

By moving the mould at the same velocity as the strip, friction problems can be removed. As the mould surface moves together with the solidifying melt the friction between them is almost absent so the thin strip can be cast with good surface quality. ${ }^{57-59)}$

\subsection{Economic Advantage}

The production of thin strip directly from the melt allows eliminating all process steps from the production route leaving only cold rolling mills and a few finishing operations, as shown in Fig. 2. Shortening the process route reduces investment cost by 4 to 10 times. ${ }^{22,26,60)}$ Specific investments per one ton of steel are expected to decrease by $40 \%$, as compared with the conventional production process (continuous casting and downstream hot rolling). ${ }^{22)}$

However, as for any new technology, there is some uncer-

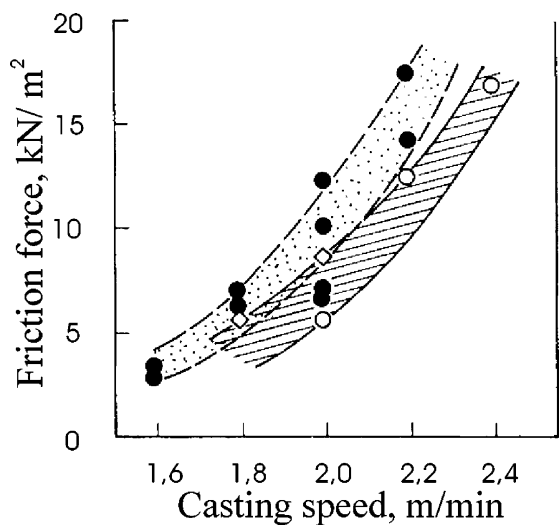

Fig. 5. Influence of casting speed on friction force between oscillation mould and slab. ${ }^{53)}$ tainty and business risk associated with the commercial implementation of the strip casting process. The business risk is mainly bound with two issues: the strip quality, which is discussed below, and the operation cost. The success of the strip casting technology in commercial application depends on operating costs, which are likely to be higher than those involved with traditional production routes, particularly in the commercialization stages. ${ }^{22)}$ Expected costs are summarized in Table 3. An accurate calculation of operation costs is still difficult because of uncertainties in the life of key components of the caster such as ceramic materials and rolls in full-scale commercial operations. In commercial application it is expected that the service life of ceramic materials is no less than three consecutive heats each of them 110 -ton. ${ }^{12)}$ The time required for changing the rolls is estimated at no longer than $10 \mathrm{~min}^{.}{ }^{12}$

The accurate calculations of the production costs also depend on the steel grade and its final application.

As for stainless steel, it is anticipated that one-ton of steel will be US\$50 to 150 cheaper in the case of casting strip compared to that of the casting of thin slabs. ${ }^{61)}$ Money is also saved due to lower transportation costs. ${ }^{51,61)}$ In stainless steel production, the ingot is typically cast at one plant, delivered to another plant for rolling and after that returned for finishing. ${ }^{29,62)}$

In the production of low-carbon $(0.06 \mathrm{wt} \% \mathrm{C})$ cast strip, only US\$20 to US\$35 per ton can be saved by strip casting compared to thin slab casting. ${ }^{61,63)}$ Lower savings are attributed to a more efficient technological route and the production cycle is contained in one location. The savings that can be made in strip casting are possible due to the higher concentrations of residual impurities, and subsequently cheaper scrap, that can be tolerated in this process. ${ }^{63)}$

Because the slag is not applied, the melt comes into direct contact with the roll surface and is solidified at a relatively high cooling rate ${ }^{64}$ (see Table 4). During solidification, the elements dissolved in the melt do not have enough time to segregate, and therefore the concentration of residual impurities may be raised without any harmful effects on strip quality. In the case of the thin slab casting, for surface cracks to be prevented, steel scrap is not to contain more than $0.15 \mathrm{wt} \% \mathrm{Cu}$, and $0.015 \mathrm{wt} \% \mathrm{Sn}^{28)}$ In the strip casting scrap with 3.5 times higher concentration of $\mathrm{Cu}$, up to $0.55 \%$, and with 10 times higher concentration of Sn up to $0.16 \%$ can be tolerated. ${ }^{51)}$

\subsection{Energy and Environment}

Apart from economic savings, the new casting technique is more energy efficient and has less environmental impact.

From semi-commercial application of the strip casting in Krefeld (Germany) within the framework of the Eurostrip project showed that the energy consumption per one ton of product is 7.5 -times lower $(0.4 \mathrm{GJ})$ than in the conventional continuous casting-hot rolling route $(3.2 \mathrm{GJ}) .{ }^{11)}$ These findings are tentative because they depend on geographic location, production structure and steel grade mix. For example, the energy savings are 2 to 5 times more in the production

Table 3. Cost comparison for steel strip product with different routes. ${ }^{22)}$

\begin{tabular}{|l|c|c|c|}
\hline & Operation process cost, \% & Capital cost absolute, \% & Capital cost per ton, \% \\
\hline Slab casting + rolling & 100 & 100 & 100 \\
\hline Thin slab casting + rolling & $90-110$ & $27-33$ & $45-55$ \\
\hline Strip casting & $135-165$ & $9-11$ & $55-65$ \\
\hline
\end{tabular}


Table 4. General parameters of conventional slab, thin slab and strip casting.

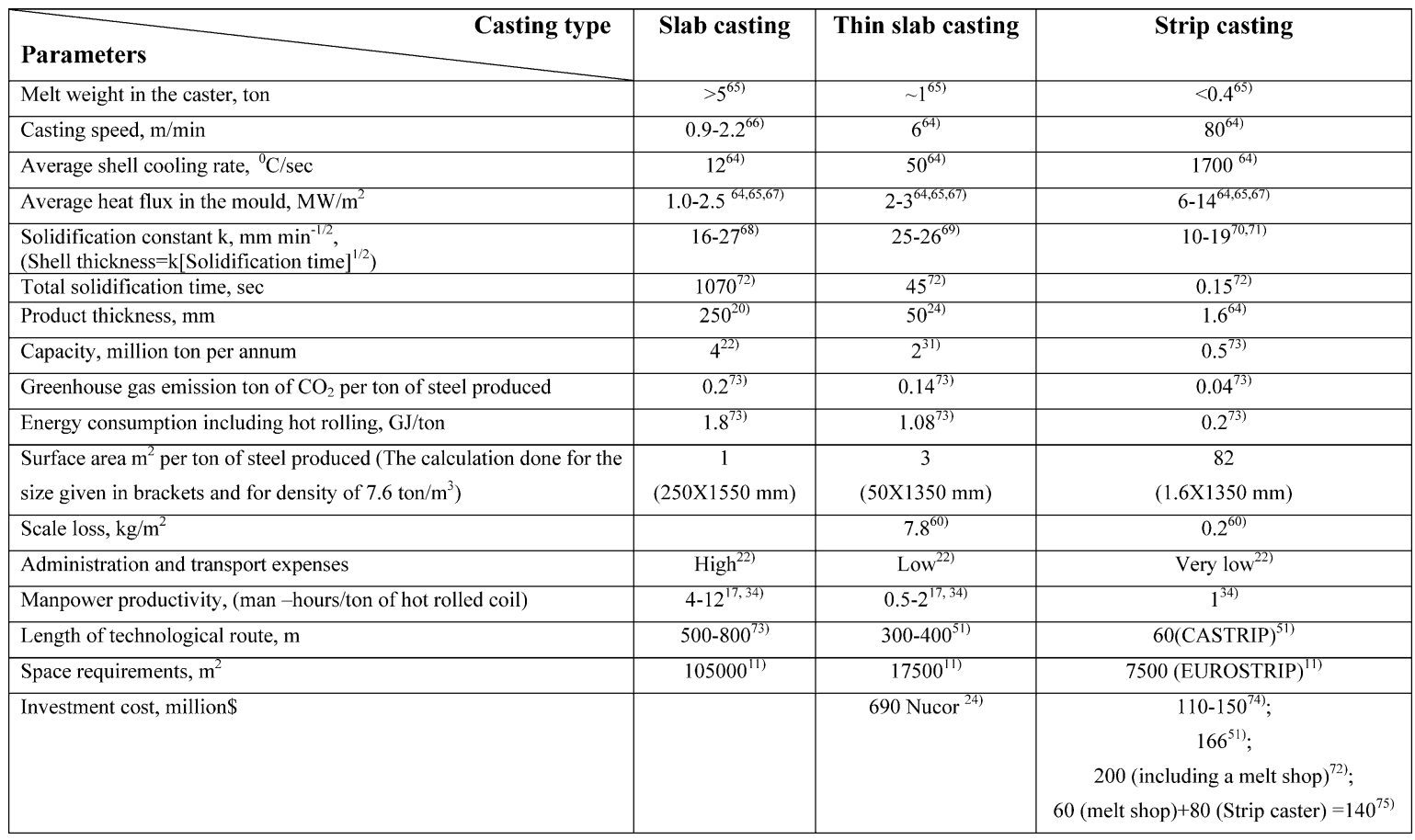

of stainless steel than in the production of carbon steel. ${ }^{61)}$

An increase in the ratio of the surface-to-mass by over 40 times (see Table 4) results in an intensive heat transfer to, or from, the environment and fast cooling, or heating, of the cast strip. This circumstance permits the as cast strip to be heated-up, if necessary, to the required temperature in a short time which additionally reduces the energy consumed for reheating and lowers steel loss due to scale. ${ }^{27,60,76,77)}$

The elimination of several intermediate reheating operations and shorter reheating times allows a reduction in deleterious gas emissions per one ton of cast steel: $\mathrm{CO}_{2}$ by $\sim 7$ times (from 185 to $25 \mathrm{~kg}$ ), $\mathrm{NO}_{x}$ by 15 times (from 290 to $10 \mathrm{~g}$ ) and $\mathrm{SO}_{2}$ by 3 times (from 50 to $15 \mathrm{~g}$ ). ${ }^{11)}$ So, application of the strip casting technology allows a reduction in the total volume of deleterious emissions such as $\mathrm{CO}_{2}, \mathrm{SO}_{2}$, $\mathrm{NO}_{x}$ of between 70 and $90 \%$ in comparison with the conventional process. ${ }^{78)}$

\subsection{Strip Manufacturing-Industry Structure}

Cast strip of 1 to $5 \mathrm{~mm}$ in thickness considerably shortens the length and duration of the production process route see Fig. 2 and Table 4 . Thus, according to the data, ${ }^{78)}$ the production of strip, starting from casting till cooling, takes no more than $15 \mathrm{~min}$ with a 60 to $150 \mathrm{~m}$-long process line. A plant with such a short production route does not require a large investment and is very flexible, easily adjusting for different steel grades, which may be required in small lots. By numerous estimates, these advantages will stimulate the construction of a new type of mill, the micro mill. ${ }^{72,79)}$ The term and trademark of "Micro-Mills ${ }^{\mathrm{TM}}$ " have already been formally registered for the type of plant based on the strip casting process. ${ }^{12)}$ It differs from the mini mill, which is based on the continuous casting of thin slabs. The micro mills can produce steel of better quality with the same or even lower price compared to the conventional thin slab casting process. The flexibility of the process will make it possible to be more accurate in meeting individual customer requirements in terms of steel grade composition, batch size and delivery time. ${ }^{62)}$

The strip casting technology can also give advantages to the existing integrated mill. The strip casting process may be incorporated in an integrated mill which has an excess steelmaking capacity to increase the range of steel grades. $^{72)}$

So, the new process offers substantial possibilities for steel producers and consumers of steel flat products.

\section{Strip Casting Process}

Late in the $1980 \mathrm{~s}$, out of the whole variety of strip casting methods based on a movable mould principal, ${ }^{24,80)}$ two techniques were selected for further research and development: feed of the melt to the surface of the rotating roll (spinning technique) and casting into the gap between two rolls rotating toward each other (twin-roll casting technique). ${ }^{24,26,81-84)}$ The main argument in favor of the singleroll strip casting was the accumulated practical experience obtained in the development of production steel strip with amorphous or microcrystalline structure. But asymmetrical crystallization and an inability to control the quality of the free surface of the cast strip in the single-roll, has seen this technique become abandoned and main efforts focused on the twin-roll technique. ${ }^{85)}$ An extra advantage of the twinroll technique is the higher production rate against the single-roll technique. ${ }^{85)}$ The productivity of the twin-roll caster is estimated at about 0.5 million ton per annum. ${ }^{73)}$ Parameters of different casters are summarized in Table 5.

Figure 6 shows schematically the typical twin-roll caster and the controlled parameters of the casting process. The steel melt flows through the ceramic nozzle to the gap between the rolls rotating toward each other. Side dams are used for forming the melt bath in the roll gap. In the process of the rolls rotation, a steel shell is being solidified adjacent each roll surface and the two shells meet and weld together before exiting the roll gap and as a result form the strip. 
ISIJ International, Vol. 43 (2003), No. 8

Table 5. Parameters of strip casters.

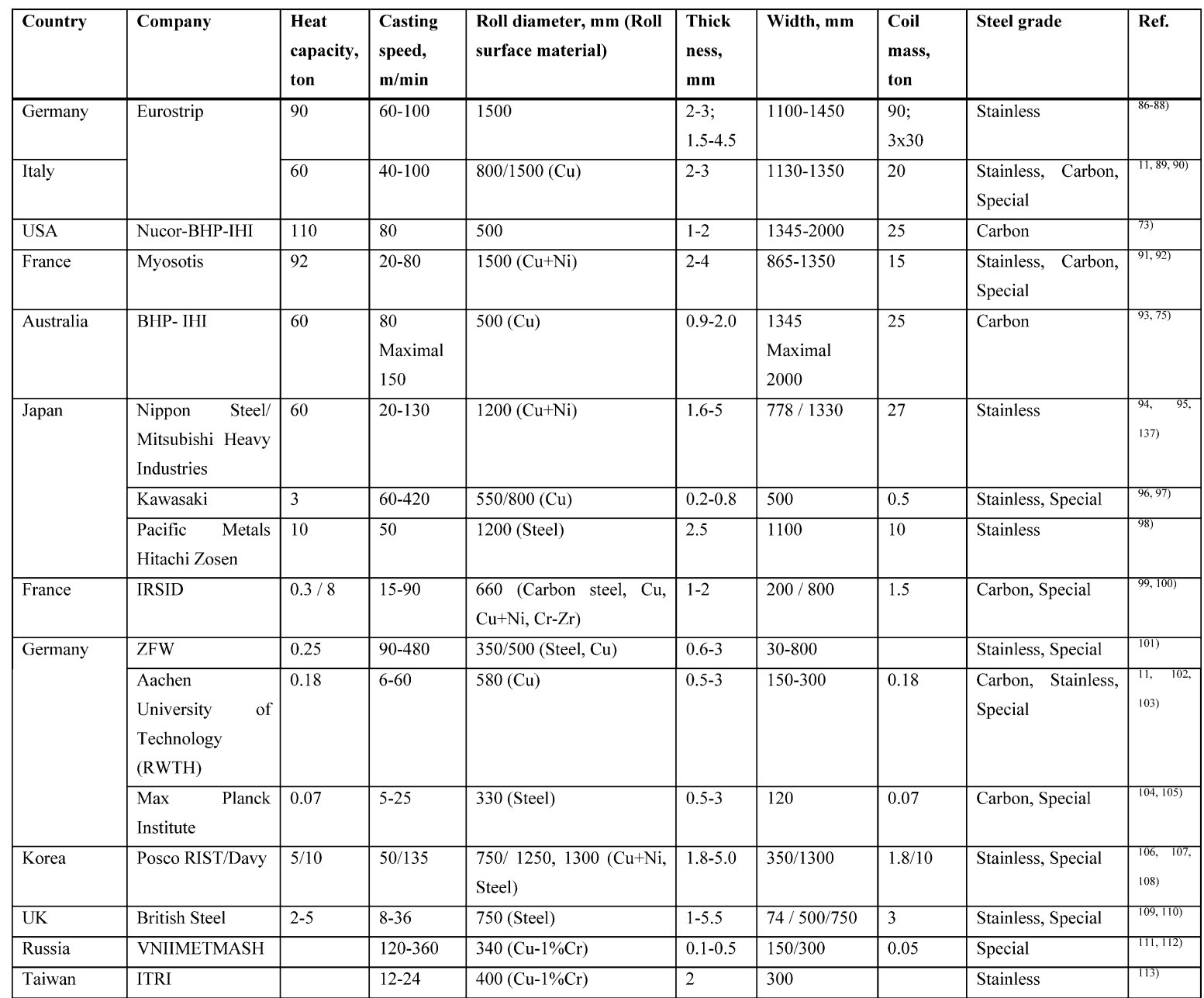

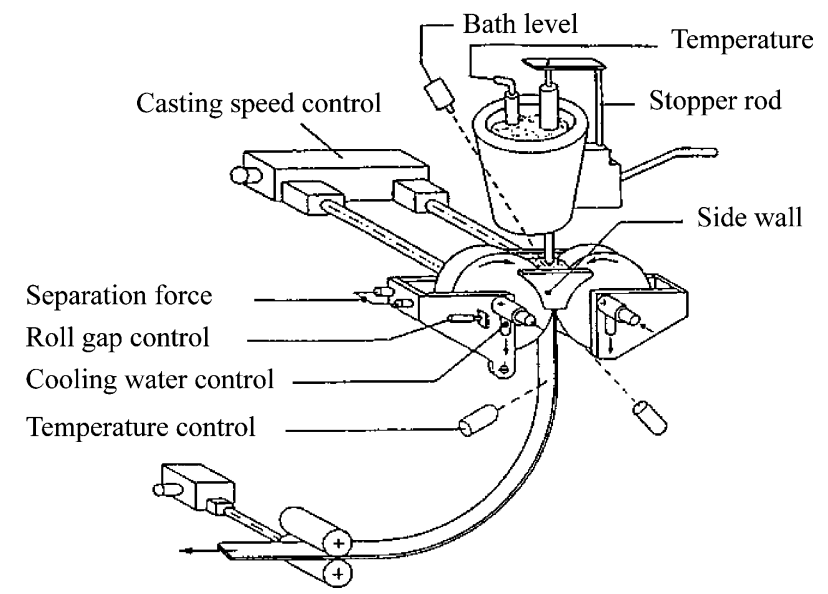

Fig. 6. Schematic view of strip caster with controlled parameters. $^{82)}$

For the shells to be welded, a roll separation force is applied. ${ }^{57,114)}$ Without the roll separation force, the shells are not welded and the molten steel flows through the roll gap (Fig. 7). In the case of high roll separation force, like in the hot rolling process, the strip is deformed and forward slip appears $^{71,115)}$ (Fig. 7). In strip casting the temperature distribution across the strip is less even than that experienced during hot-rolling. This results in higher deformation in the strip casting in comparison with conventional hot rolling process. ${ }^{116)}$ The rate of deformation in the casting direction

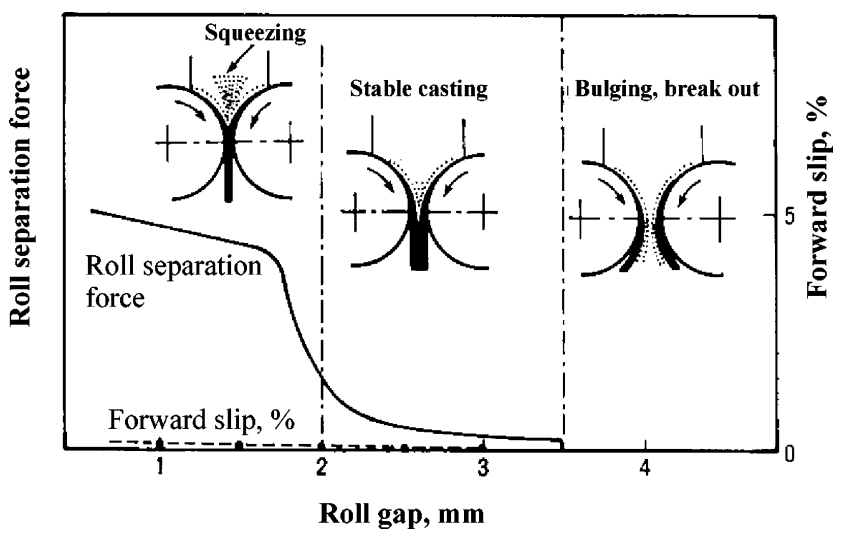

Fig. 7. Influence of the roll separation force on state of the casting process and the strip forward slip. ${ }^{71}$

is dependent on many variables, ${ }^{102)}$ and may be greater in the backward direction than in the forward direction. ${ }^{117)}$

Too high a pressure causes excessive strip deformation and this is not desirable as it leads to segregation of lowmelting point elements that crystallize late in solidification. ${ }^{71,105)}$

The temperature of the molten steel for casting is kept as low as possible for increasing the production rate ${ }^{70)}$ (Fig. 8) and reducing surface crack formation. ${ }^{118)}$ However, it can be beneficial to control the temperature cycle of the melt prior to casting as it is possible to increase the strip quality 


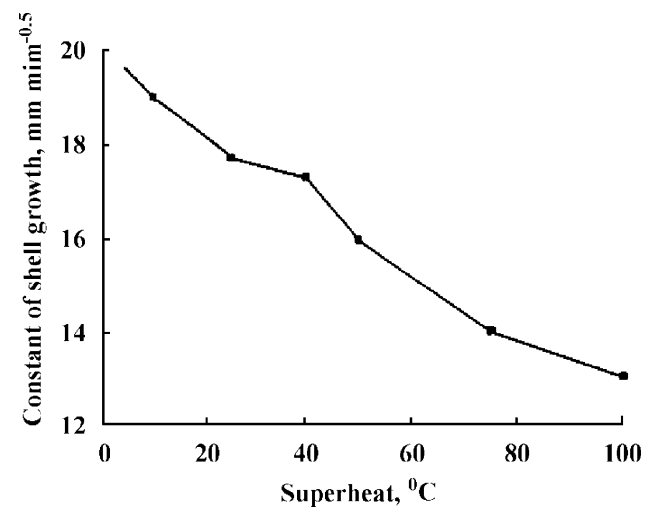

Fig. 8. Influence of melt superheat temperature on constant solidification of shell growth. ${ }^{70)}$

Shell thickness $=($ Constant solidification $) \cdot($ Solidification time). ${ }^{1 / 2}$
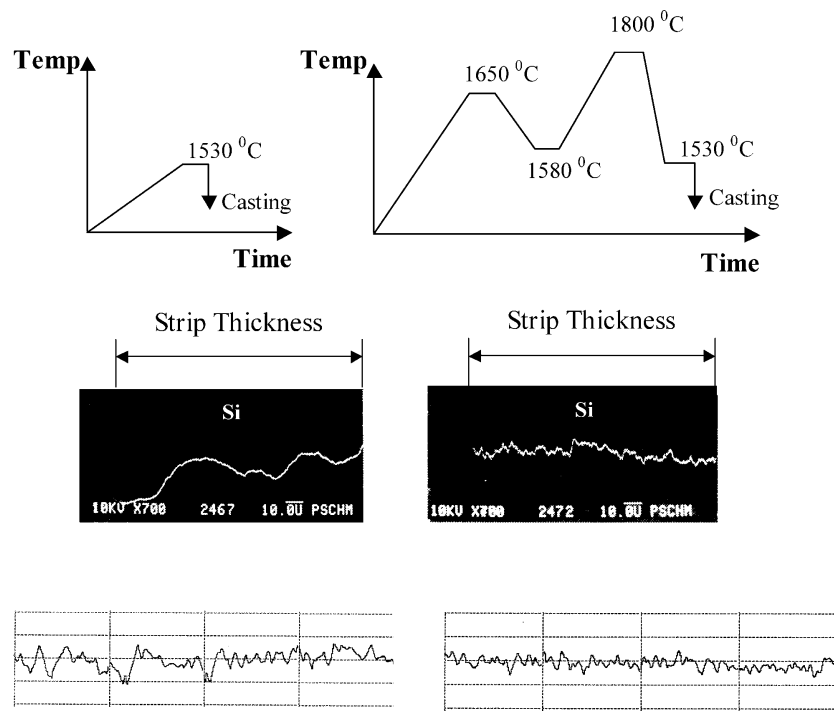

$\mu \mathrm{m}$

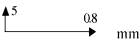

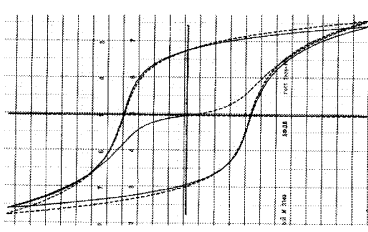

a.

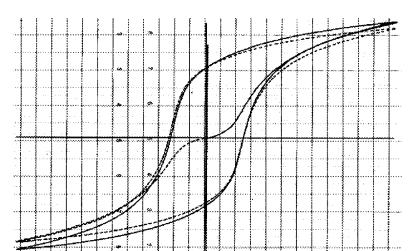

b.
Fig. 9. Effect of liquid steel preparation by temperature cycle (a) and (b) on segregation across strip thickness, strip surface roughness and internal stress in as cast strip. ${ }^{119)}$ Area of hysteresis cycle is used as indication of internal stress. The bigger area represents the higher internal stress.

by decreasing segregation and internal stresses in the strip $^{119)}$ (Fig. 9).

The productivity of a strip caster depends on casting speed and the thickness of the strip. The analysis of the available data for commercial scale casters plotted as productivity versus casting speed is shown in Fig. 10 which gives a regression relation of Productivity-Casting speed $^{-0.5}$.

The scattering of the data from the average linear fit may be explained by differences in the roll diameter, the surface coated material and the roll surface micro-topography (see

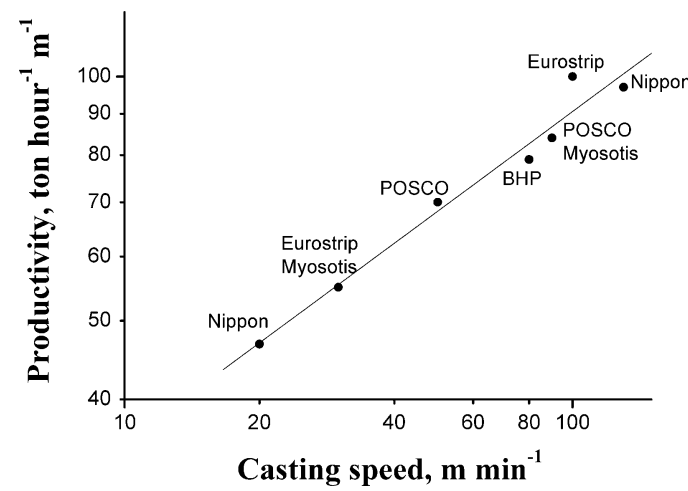

Fig. 10. Relation between speed of strip casting and productivity of caster per hour, per meter of roll width. The thickness of cast strip and casting speed are taken from data. $9,11,75,91,108)$ The density of steel is accepted as 7.8 ton $\mathrm{m}^{-3}$ from Ref. 120).

Table 5).

Larger diameter rolls have a deeper bath melt pool, a higher capacity to absorb heat and increase the production rate. ${ }^{88)}$ Additionally the length of the deformation zone between the rolls increases with the roll diameter and this creates a more stable casting process. ${ }^{102)}$ However the upper diameter of the rolls is limited by the practicalities of designing a ceramic nozzle to deliver the melt. Additionally, the higher the diameter of the rolls the larger and more expensive are the ceramic side dams necessary for containing the melt. The analysis of the commercial casters shows that there is still no consensus on the optimal roll diameter. Castrip uses rolls of $0.5 \mathrm{~m}$ in diameter while Nippon prefers $1.2 \mathrm{~m}$ and Eurostrip $1.5 \mathrm{~m}$ (see Table 5).

Analysis of the actual roll surface material and roll surface micro topography used in the commercial scale casters is not possible at present as it is a commercially sensitive features of the caster design which determines not only the productivity of the caster but also contributes to the total quality of the cast strip. The available information on the roll surface features published in the open literature result from fundamental or general studies and is reviewed below.

The ceramic side dams whose life and price affect the profitability of the caster are one of the most expensive components of the caster. ${ }^{121}$ ) The dam should be tight against the roll ends, wear-resistant, sustain an enormous temperature gradient between the cold roll end and liquid steel. Boron nitride-based ceramics have been found to be the most suitable material. ${ }^{122,123)}$

\section{Strip Quality}

Casting strip of thickness 1-2 mm leaves almost no possibility for additional treatments to rectify its quality, moreover, additional processing can eliminate all the economic advantages of the strip casting process. ${ }^{124)}$ For these reasons, the requirements on the surface quality, geometry and properties of the cast strip are high. ${ }^{64)}$ The high casting velocity and rapid solidification demand an accurate control of any process parameters because even slight deviations lead to a substantial deterioration of the strip quality.

\subsection{Surface Cracks}

In continuous casting practices it is known larger heat fluxes drastically increase the possibility of surface crack- 


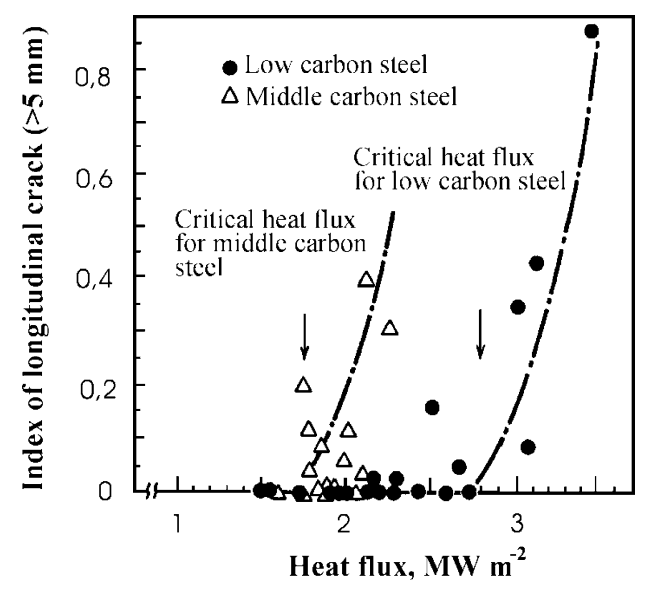

Fig. 11. Influence of heat flux in mould on longitudinal surface cracks obtained for low $(0.05 \mathrm{wt} \%$ C) and middle $(0.11 \mathrm{wt} \% \mathrm{C})$ carbon steel. ${ }^{125)}$

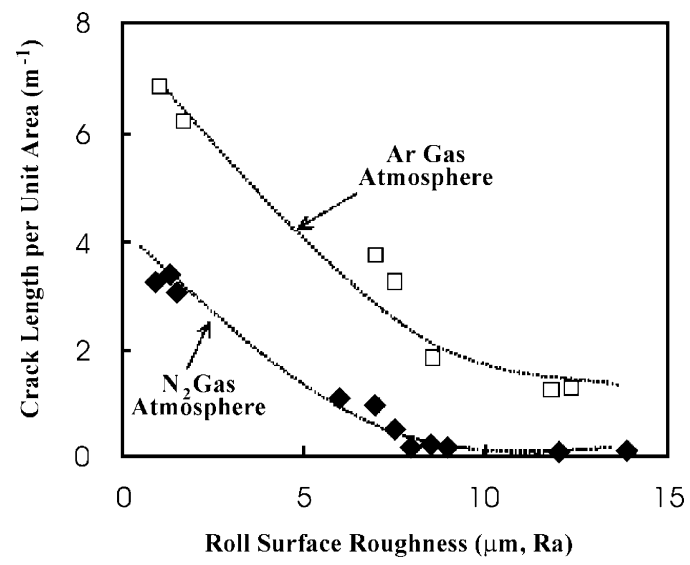

Fig. 12. Relation between crack length per unit area of strips and roll surface roughness for casting in argon and nitrogen atmospheres. ${ }^{108)}$

ing by induced additional internal stress during solidification. ${ }^{125)}$ The critical heat flux, which, if exceeded, causes cracks on low- and middle-carbon steel strip, is indicated in Fig. 11.

As mentioned previously, slag is not required as a lubricant in the strip casting process. Although slag reduces friction at the roll surface, it increases the heat flux to levels several times the critical level shown in Table 4. This increases the difficulty of ensuring high-quality strip from the strip casting process.

The problem can be solved by a combination of measures. ${ }^{126)}$ Selection of a coating material ${ }^{100,127)}$ in combination with a special roll surface roughness, ${ }^{64,108,126,128)}$ roll separation force ${ }^{129)}$ and a protective atmosphere ${ }^{108,130)}$ permit heat flux and internal stress to be lowered and made more uniform. Different materials based on nickel, chrome or ceramics ${ }^{92,126)}$ are applied as coatings. The effect of the roll surface roughness and the protective inert atmosphere on the appearance of surface cracks is shown in Fig. 12.

Turbulent flows ${ }^{131)}$ and ripples on the melt surface ${ }^{132)}$ may cause cracks on the strip surface. The nozzle must be designed to lower the amplitude of surface waves ${ }^{133)}$ as shown in the design of the submerged nozzle ${ }^{134)}$ in Fig. 13. The ceramic nozzle must also be inert with respect to the melt otherwise surface defects will appear. ${ }^{64)}$ Reducing the

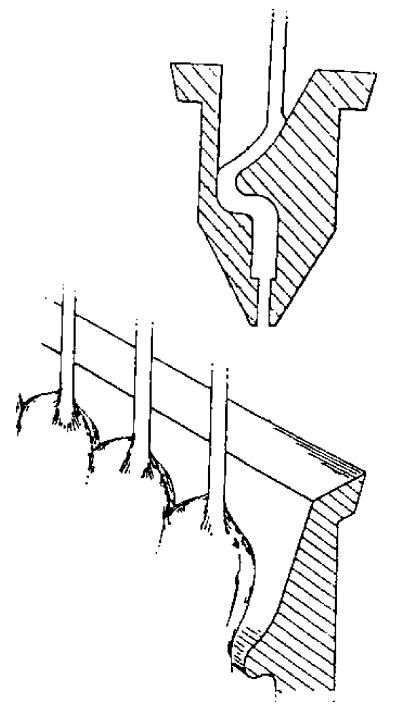

Fig. 13. Submerged nozzle. ${ }^{134)}$

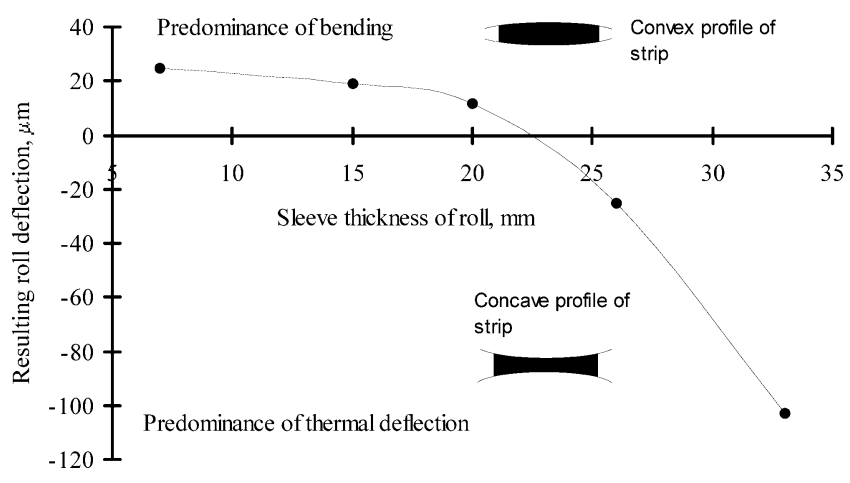

Fig. 14. Influence of thickness of the roll sleeve on total roll deflection and the shape of the strip profile. ${ }^{112)}$ The resulting roll deflection is calculated as: (Resulting roll deflection $)=($ Bending deflection $)-($ Thermal deflection $)$.

roll separation force is one of the measures used to prevent surface cracks. ${ }^{99,105)}$

\subsection{Uneven Strip Thickness}

During casting the rolls are not uniformly heated, changing their initial profile. ${ }^{112)}$ At operating temperature the roll profile has to be stable and shaped to ensure uniform thickness of strip with minimum irregularities and good flatness. A correctly designed roll profile combined with a watercooled roll sleeve of an optimal thickness and material, permits thickness irregularities to be minimized ${ }^{3,110,112,135)}$ as shown in Fig. 14.

Another reason for irregularities in thickness is due to the different heat transfer conditions at the side dams compared to the central part of the roll. This causes more irregularities in the thickness at the strip edges. ${ }^{64)}$ To rectify the strip geometry a hot rolling mill is installed in line before the coiler and the strip edges are trimmed as shown Fig. 15. Table 6 gives the tolerances of the cast strip thickness required according to standards in various countries for hot rolled products. To be an acceptable alternative to hot rolling, strip casting must produce products that meet or exceed these standards.

\subsection{Strip Flatness}

The out of the cast strip flatness may be characterized by 


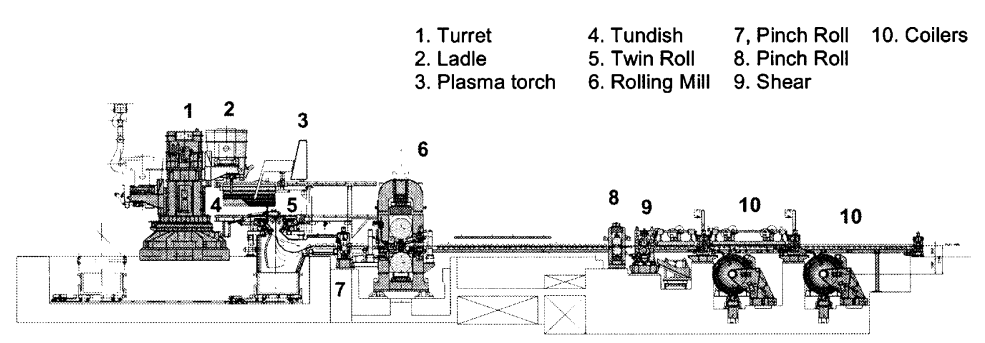

a.

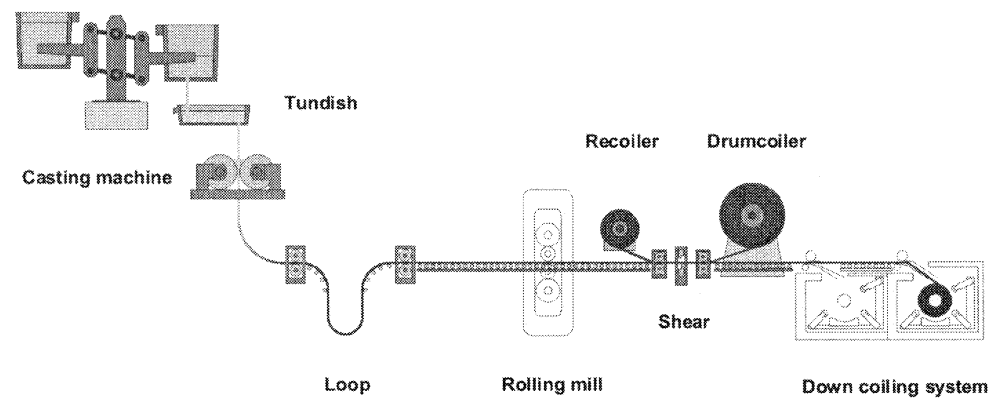

b.

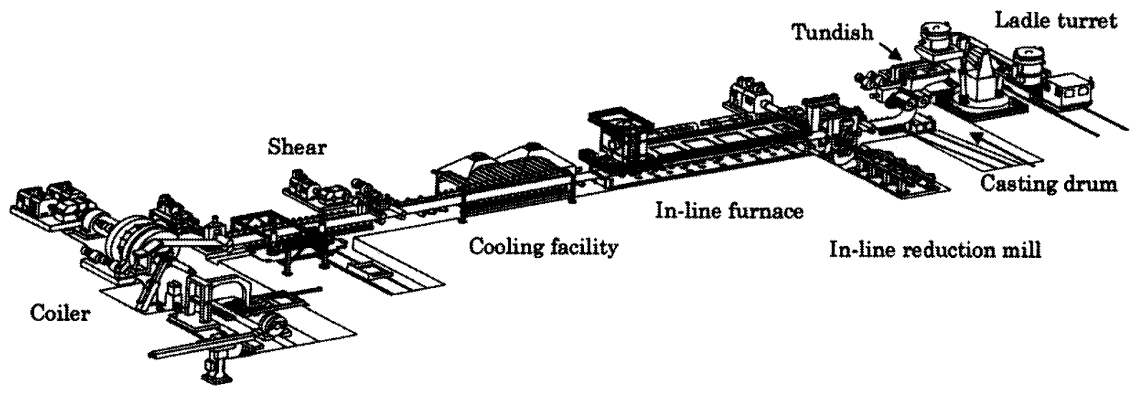

c.

Fig. 15. Main strip casters: (a) The basic component of BHP-IHI caster ${ }^{136)}$ used by CASTRIP. (b) Eurostrip. ${ }^{87)}$ (c) Nippon Steel Corporation and Mitsubishi Heavy Industries. ${ }^{137)}$

Table 6. Thickness and flatness variation of as cast strip in comparison with standard tolerance requirements for different countries. Data for as cast strip taken for low carbon steel with strip width $1345 \mathrm{~mm} .{ }^{136)}$

\begin{tabular}{|c|c|c|c|}
\hline & & As-cast & As cast + hot rolled \\
\hline \multicolumn{2}{|l|}{ Strip thickness, mm } & $1.6-1.9$ & $1.0-1.4$ \\
\hline \multicolumn{2}{|l|}{ Centreling gauge variation, $\mathbf{m m}$} & \pm 0.054 & \pm 0.034 \\
\hline \multicolumn{2}{|l|}{ Full width variation ( $25 \mathrm{~mm}$ side trim) } & \pm 0.103 & \pm 0.045 \\
\hline \multicolumn{2}{|l|}{ Full width variation (50 $\mathrm{mm}$ side trim) } & \pm 0.077 & \pm 0.042 \\
\hline \multicolumn{2}{|l|}{ Out of Flatness, $\%$} & $2.0-2.8$ & $2.0-6.0$ \\
\hline Standard requirements & Country, Standard & & \\
\hline \multirow{4}{*}{$\begin{array}{l}\text { Thickness tolerance for hot rolled sheet, } \\
\text { mm }\end{array}$} & USA, ASTM & \pm 0.18 & \pm 0.18 \\
\hline & Germany, DIN 1541-32 & \pm 0.14 & $\pm 0.09- \pm 0.12$ \\
\hline & Japan, JIS G 3131-67 & \pm 0.16 & \pm 0.16 \\
\hline & Europe, Euronorm 26-69, 33-70 & \pm 0.15 & $\pm 0.10- \pm 0.12$ \\
\hline $\begin{array}{l}\text { Out of Flatness tolerance for hot rolled } \\
\text { sheet, \% }\end{array}$ & Japan, JIS G 3193-70 & $0.2-0.7$ & \\
\hline
\end{tabular}

$(A / S) \times 100 \%$, where $(A)$ is the amplitude of a strip deviation from the flat surface and $(S)$ is the wavelength. The out of flatness may be caused by uneven thermal and structural changes taking place in the strip during crystallization and cooling and non-uniform plastic deformation in the roll gap. Table 6 gives the flatness of the hot-rolled product required in various standards. As for surface thickness these standards must be within the capabilities of the strip casting process. Deterioration of strip flatness after hot rolling occurs due to non-uniform deformation across the width of the cast strip. ${ }^{136)}$ The strip flatness is improved by cold rolling with tension applied by the coiler. ${ }^{136}$

\section{Commercial Strip Casters}

For the last twenty years different steelmaking companies have been developing the strip casting technology. Some projects were stopped and others united in order to reduce finical expenditure. The companies' cooperation and the status of the projects are presented in Fig. 16. 


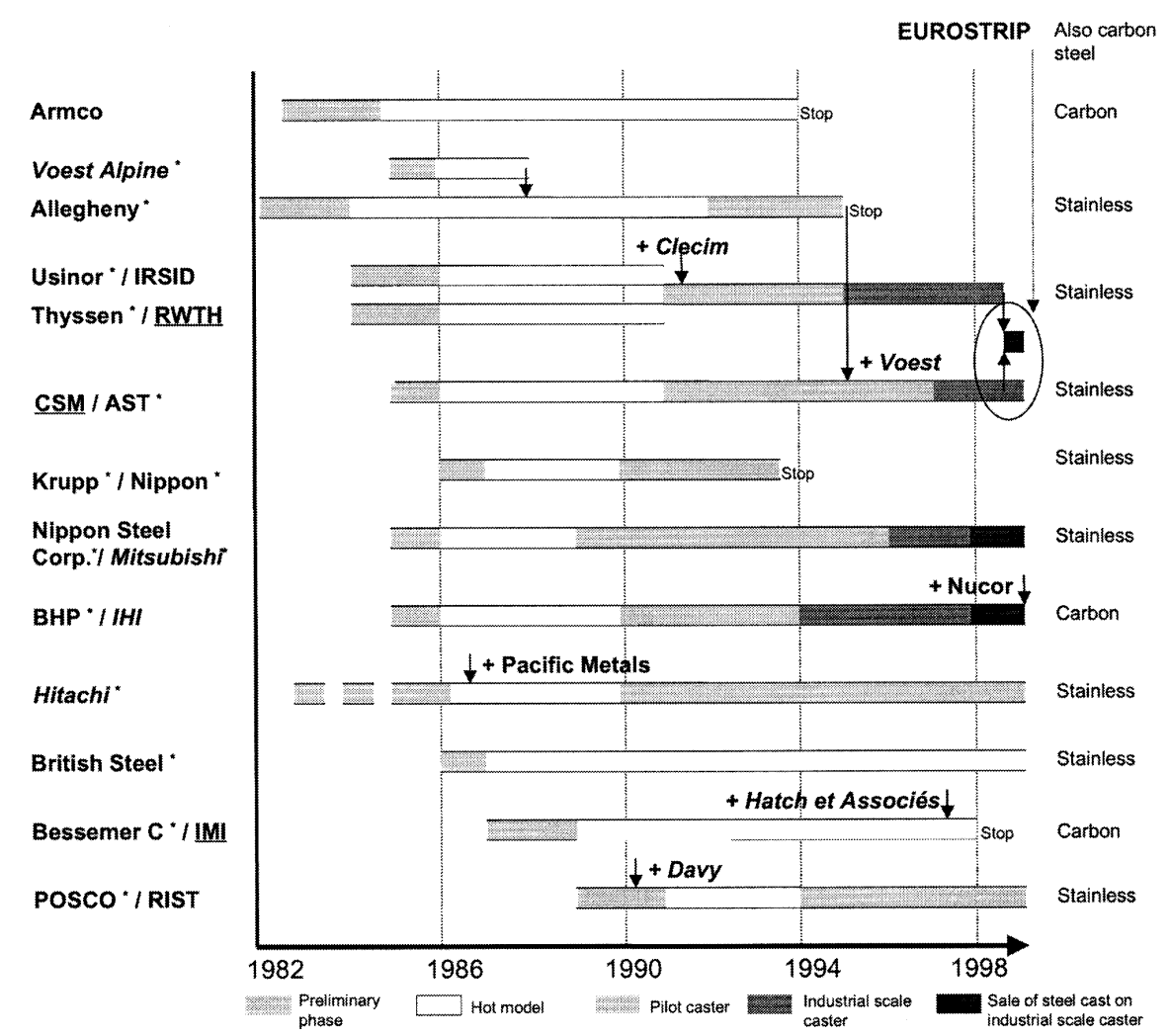

Fig. 16. Company collaboration and status of projects ${ }^{138)}$ (Nippon Yakin Kogyo Co. Ltd. named as Nippon).

Table 7. Properties of a strip obtained through conventional and cast strip technological routes.

\begin{tabular}{|l|l|c|c|}
\hline Steel grade & Properties & Conventional route & Strip casting \\
\hline \multirow{3}{*}{ Hot rolled Low carbon steel G550/Grade 80 } & Tensile strength, MPa & 767 & 850 \\
\cline { 2 - 4 } & Elongation, \% & 4.7 & 4.5 \\
\hline \multirow{3}{*}{ Hot rolled Low carbon steel G300/Grade 40 } & Yield strength, MPa & 320 & 315 \\
\cline { 2 - 4 } & Tensile strength, MPa & 390 & 416 \\
\cline { 2 - 4 } & Elongation, \% & 36 & 36 \\
\hline Cold rolled Stainless steel AISI 3048, 91) & $\mathrm{Rp}_{02}, \mathrm{MPa}$ & $240-350$ & 330 \\
\cline { 2 - 4 } & $\mathrm{Rm}, \mathrm{MPa}$ & $590-690$ & 670 \\
\cline { 2 - 4 } & $\mathrm{A}_{80}$, & $50-60$ & 53 \\
\cline { 2 - 4 } & Hardness $\mathrm{HV}_{30}$ & 150 & $167-198$ \\
\cline { 2 - 4 } & Surface roughness, $\mathrm{Rz}, \mu \mathrm{m}$ & $0.9-1.5$ & 1.2 \\
\cline { 2 - 4 } & Pitting potential, $\mathrm{mV} / \mathrm{H}$ & $400-550$ & 600 \\
\hline
\end{tabular}

Five commercial-scale casters have been built for estimating the process feasibility and evaluating techno-economic parameters: BHP-IHI (Australia), Nippon SteelMitsubishi Heavy Industries (Japan), Myosotis (France), Acciai Speciali Terni (Italy) and Eurostrip (Germany). Three of the casters are being intensively prepared for fullscale commissioning: Castrip (USA), Eurostrip (Germany) and Nippon Steel-Mitsubishi Heavy Industries (Japan).

\subsection{Castrip}

Broken Hill Proprietary Ltd., (BHP), an Australian steelmaker, and Ishikawajima-Harima Heavy Industries (IHI), a Japanese machine-builder, have studied strip casting since $1989 .^{75)}$ In 1995 a full-scale machine for casting carbon steels was constructed in Port Kembla, Australia. For testing properties, parts of the cast strip were cold rolled to $0.42 \mathrm{~mm}$, coated with $55 \% \mathrm{Al}+\mathrm{Zn}$ and applied as roofing in housing as well as for the production of square $25 \times 25$, $50 \times 50 \mathrm{~mm}$ and round $21.3-88.9 \mathrm{~mm}$-diameter tubes. ${ }^{75)}$ Table 7 presents the properties of the cast strip from lowcarbon steel.
In March 2000, Nucor joined BHP-IHI and established Castrip Limited Liability Company (Castrip LLC), with Nucor and BHP each owning $47.5 \%$ and $5 \%$ owned by IHI. ${ }^{12)}$ Having obtained the first license from Castrip, in spring 2002 Nucor completed the construction and started production operations of cast strip in Crawfordsville, Indiana, USA.

The basic component of BHP's caster Fig. 15(a) were dismantled and delivered from Australia, to the USA. A 110-ton electric arc furnace (EAF) is used for steel melting. The plant is designed for production of carbon steel and stainless strip. To develop the strip casting process, Nucor is going to spend an additional US\$100 million. ${ }^{12)}$ The target of Castrip is to ensure the stability of cast strip production quality firstly for carbon steel and later for stainless steel. The main application of the low-carbon steel strip is for roofing, tanks, power unit boxes, furniture frames, etc. At present the Castrip technology is protected by 1500 patents worldwide. ${ }^{72)}$ After the technology is proven, the company intends to sell it and will continue to invest in technology to cast wider and thinner strips. ${ }^{139)}$ 


\subsection{Eurostrip}

In September 1999, after several years of independent R\&D on strip casting, Thyssen-Krupp Steel, Usinor and Voest Alpine Industrieanlagenbau established Eurostrip, a European company ${ }^{11,79)}$ (see Fig. 15(b)). The companies task is to develop a commercial technology for stainless and carbon steel strip casting. ${ }^{11)}$ A strip casting shop was built at the Krupp Thyssen Nirosta plant in Krefeld, Germany. ${ }^{41)}$ The plant produces stainless steel and has no hot rolling facilities. Therefore the strip casting shop is incorporated as a missing link in the production route between the steelmaking and cold rolling shops. ${ }^{87)}$

Eurostrip has a second commercial-scale caster located in Terni, Italy, which is used for developing the casting of carbon and silicon steels. ${ }^{86,87)}$ Before the merger with Thyssen-Krupp, Acciai Speciali Terni (AST) and Centro Sviluppo Materiali (CSM), a research institution in Terni, Italy, carried out investigations using this commercial-scale caster. ${ }^{89)}$ The strip casting fundamentals are being studied using a laboratory caster located in Aachen University of Technology (RWTH), Aachen, Germany. ${ }^{11)}$

Early in 2003 it is planned to bring the Krefeld mill to the full capacity with a production rate of 0.4 million ton per annum. ${ }^{86,87)}$ Currently more than 1000 patents protect the Eurostrip technology. ${ }^{78)}$ The properties of the cast stainless strip are presented in Table 7. The stainless steel strip will be used for kitchenware and sinks.

\subsection{Nippon Steel Corporation and Mitsubishi Heavy Industries}

Nippon Steel Corporation, a steelmaker, and Mitsubishi Heavy Industries, a machine-builder, have pursued a R\&D program aimed at casting stainless steels since $1985 .{ }^{95)}$ In 1997, a commersial machine for casting of austenitic stainless steel was constructed at Nippon Steel's Hikari Works (Japan) ${ }^{140)}$ (Fig. 15(c)). In 1998, the casting unit reached a capacity of 20000 ton per month. ${ }^{63)}$ In 1996 the project cost was estimated at $¥ 11$ billion $^{141)}$ (\$110 million $\left.^{63)}\right)$.

For technological improvements, in 2000 Nippon Steel and POSCO, a Korean company, which has long been carrying similar studies, formed an agreement to share in the research and development of strip casting technology. ${ }^{142)}$

\subsection{SMS Demag and MAIN AG/MTA, Danieli}

In August 2000, an agreement on the start of construction of a full-commercial scale caster for the production of stainless and carbon steel strip was signed between SMS (Germany) and MAIN AG/MTA (Switzerland). ${ }^{143)}$

There has been substantial interest in the strip casting process by a variety of supporting industries that would benefit from the large scale commercialization of the new technology. For example Danieli, a large manufacturer of plant equipment has indicated their interest and the first industrial strip caster for carbon and stainless steel with a capacity of $0.6-0.7$ million ton per annum is being built at ABC (Italy). ${ }^{144)}$

\section{Expenditure on Research and Development of Strip Casting Technology}

A substantial reduction of deleterious emissions and energy savings in the replacement of traditional technology with strip casting process is expected. The new technology is actively supported by several national governments with the help of state organizations: European Coal and Steel Community (ECS) in Europe, US Department of Energy in the US, and The Canadian National Research Council in Canada. It must be noted that governments provided financial support only at early R\&D stages, which involved fundamental investigations. A transition from pilot to commercial production in the conditions of stiff competition and large potential profits has resulted in companies carrying out independent, self-funded research projects and restricting access to any results. Table 8 illustrates the sources of

Table 8. Expenditure on research and development of strip casting technology and share of government support

\begin{tabular}{|c|c|c|c|c|}
\hline Company & Scale & $\begin{array}{c}\text { Total expenditure, } \\
\text { million \$ }\end{array}$ & $\begin{array}{c}\text { Government support, } \\
\text { million } \$\end{array}$ & Name of Government support organization \\
\hline Armco $^{138)}$ & Pilot & 17 & 12 & US Department of Energy \\
\hline Allegheny ${ }^{138)}$ & Pilot & $10-15$ & & \\
\hline Usinor/Thysson ${ }^{138)}$ & $\begin{array}{l}\text { Pilot } \\
\text { Industrial }\end{array}$ & $\begin{array}{l}10 \\
100\end{array}$ & $\begin{array}{c}1.4 \\
\text { limited }\end{array}$ & $\begin{array}{l}\text { European Coal and Steel Community, German Bundesland } \\
\text { and } \\
\text { French Government }\end{array}$ \\
\hline CASTRIP $^{139)}$ & Industrial & 400 & & \\
\hline $\begin{array}{l}\text { CSM/AST } \\
\text { Voest }^{138)}\end{array}$ & $\begin{array}{l}\text { Pilot } \\
\text { Industrial }\end{array}$ & $\begin{array}{c}15-20 \\
\text { unknown }\end{array}$ & $\begin{array}{l}4.1 \\
5\end{array}$ & European Coal and Steel Community \\
\hline $\begin{array}{l}\text { Krupp Stahl// } \\
\text { Nippon Yakin }{ }^{138)}\end{array}$ & Pilot & unknown & 0.6 & European Coal and Steel Community and German Bundesland \\
\hline EUROSTRIP $^{138)}$ & Industrial & 50 & & \\
\hline $\begin{array}{l}\text { Nippon Steel/ } \\
\text { Mitsubishi }^{63)}\end{array}$ & Industrial & 110 & & \\
\hline $\mathrm{BHP} / \mathrm{IHI}^{145)}$ & Industrial & 250 & & \\
\hline Pacific Metals/ Hitachi $^{138)}$ & Pilot & Unknown & & \\
\hline British Steel $^{138)}$ & $\begin{array}{l}\text { Hot } \\
\text { model }\end{array}$ & 4 & 1.7 & European Coal and Steel Community \\
\hline Bessemer/IMI ${ }^{61)}$ & $\begin{array}{l}\text { Hot } \\
\text { model }\end{array}$ & 26 & 13 & National Resources Canada \\
\hline POSCO/Davy ${ }^{146)}$ & Pilot & 78 & & \\
\hline Total & & 1080 & 30 & \\
\hline
\end{tabular}


funding for the development of the strip casting process. The total cost of the studies, inclusive of fundamental but indirectly connected research, is somewhat higher. For instance, in the European Union alone, in the period from 1986 to 1999 , through the ECS, about US\$18 million $^{138,147)}$ was spent on strip casting, $20 \%$ of the whole budget of US\$89 million allocated for the entire R\&D related to casting, including fundamental $\mathrm{R} \& \mathrm{D}^{147}$ ) (for easier conversion US\$ $1=€ 1)$.

\section{Conclusion}

Increased competition and the need to decrease steel product prices has combined with other factors such as growing salaries and the increasing cost for electricity and raw materials to apply pressure to both mini and integrated mills. To compete in the future market and to maintain market share, both mills will need to use new efficient technologies capable of supplying steel strip products of high quality at low cost. Large investments in the development of strip casting process by the main world steel produces and manufacturers of plant equipment have already occurred due to its huge potential to substantially reduce the investment cost of steel strip production, which is now at a stage of industrial implementation for the production of stainless and low-carbon steels

The technology is well suited for micro mills, which can produce steel strip of composition required by individual customers. Comparatively small investments, flexibility and the low environmental impact nature of the new technology permits it to be introduced in regions with relatively small resources of raw materials, for example, in regions which have sufficient supplies of metallic scrap. The strip casting technology can also give advantages to the existing integrated mill. The strip casting process may be incorporated in an integrated mill, which has an excess steelmaking capacity to increase the range of steel grades.

\section{REFERENCES}

1) H. Bessemer: J. Iron Steel Inst., (1891), 1

2) H. Bessemer: US Patent 49053, July 25, (1865).

3) V. V. Gusev: Liteinoe Proizvodstvo, (1952), No. 11, 5.

4) S. Shiozawa, T. Kusakawa and Y. Matsuura: Sosei to Kako, 1 (1960), 99.

5) M. Cygler and M. Wolf: Iron Steelmaker, 13 (1986), No. 8, 27.

6) W. E. Stephens and G. R. Vassily: Light Metals 1971, The Metallurgical Society, New York, (1971), 535.

7) D. Altenpohl and P. J. Uggowitzer: Aluminium, 77 (2001), No. 10, 754.

8) M. M. Wolf: $B H M, 145$ (2000), No. 1, 35.

9) K. Yanagi, K. Sasaki, K. Yamamoto, H. Takeuchi and H. Nakashima: Mitsubishi Heavy Ind., Tech. Rev., 33 (1996), No. 1, 26.

10) S. Watanabe: Nippon Steel Tech. Rep., 71 (1996), October, 1.

11) H.-U. Lindenberg, U. Albrecht-Fruh, M. Walter, R. Capotosti, G. Stebner and D. Senk: Forum-Technische Mitteilungen Thyssen Krupp (English Edition), (2000), December, 20.

12) R. Wechsler: Steel Times, 229 (2001), No. 1, 23.

13) A. J. Hulek and O. Harrer: Metall. Plant Technol. Int., 3 (1997), 84.

14) R. Nystrom, W. Reichelt and M. Dubke: Scand. J. Metall., 29 (2000), No. 3, 93.

15) K. Schwerdtfeger, K.-H. Spitzer, J. Kroos, P. Funke and K.-H. Hower: ISIJ Int., 40 (2000), 756.

16) H. Jones: Rapid Solidification of Metals and Alloys, The Institute of Metallurgists, London, (1983), 83.

17) H. Wiesinger: Iron Steelmaker, 24 (1997), No. 12, 33.
18) R. M. Cyert and R. J. Fruehan: The Basic of Steel Industry, Meeting the US Industry Faces the 21st Century, US Department of Commerce Office of Technology Policy, Pittsburgh, (1996), 62.

19) E. Schulz, D. Ameling, B. Gerstenberg, E. Hoffken, K. H. Peters and R.W. Simon: Metall. Plant Technol. Int., 13 (1990), No. 5, 32.

20) M. M. Wolf: 75th Steelmaking Conf. Proc., ISS, Warrendale, PA, (1992), 83.

21) M. Tsukigahora, H. Sakaguchi, K. Sasaki, S. Suzuki, T. Kato and M. Tanigawa: The Hitachi Zosen Tech. Rev., 54 (1993), No. 2, 2.

22) C. Hendricks: Metall. Plant Technol. Int., 18 (1995), No. 3, 42.

23) W. Bald, G. Kneppe, D. Rosenthal and P. Sudau: Steel Times Int., 24 (2000), No. 5, 16.

24) A. Trupiano: Metall. Ital., 89 (1997), No. 7-8, 31.

25) T. Watanabe: Tetsu-to-Hagané, 88 (2002), No. 3, 107.

26) J. P. Birat, R. Steffen and S. Wilmotte: European Commission Technical Steel Research, EUR 16671 en (1995), 198.

27) A. Flick, G. Lettmayr, A. Wagner and A. Bumberger: Steel Times Int., 24 (2000), No. 3, 17.

28) S. L. Wigman and M. D. Millett: Scanijet VI; 6th Int. Conf. Refining Processes, MEFOS, Lulea, Sweden, (1992), 1.

29) P. Nilles: Metall. Plant Technol. Int., 17 (1994), No. 3, 46.

30) B. V. Molotilov, A. A. Brodov and V. I. Matorin: Steel in Translation, 27 (1997), No. 9, 1

31) J. Aylen: Steel Times, 229 (2001), No. 7-8, 227.

32) H. Malinowski: Steel Times, 217 (1989), No. 11, 600.

33) D. Ameling: Stahl Eisen, 120 (2000), No. 9, 27.

34) H. Wiesinger: Steel Times, 228 (2000), No. 8, 299

35) C. Fine, R. Clair, J. Lafrance and D. Hillebrand: The US Automobile Manufacturing Industry, US Department of Commerce Office of Technology Policy, USA, (1996), 102.

36) K. Noro, M. Takeuchi and Y. Mizukami: ISIJ Int., 37 (1997), 198.

37) L. Savov and D. Janke: Metall., 52 (1998), No. 6, 374.

38) J. J. Poveromo: Proc. of Gerald Heffernan Int. Symp. on Innovative Technology for Steel and Other Materials, CIM, Montreal, Canada, (2001), 39.

39) J.-P. Birat: Rev. Métall., Cah. Inf. Tech., 98 (2001), No. 1, 19

40) S. Millman: Steel Times, 228 (2000), No. 1, 20.

41) R. Barrett: Met. Bull. Monthly, 369 (2001), September, 18.

42) J.-P. Birat: Ironmaking Steelmaking, 28 (2001), No. 2, 152.

43) A. Otto: Symp. Stainless Steel in Architecture, The European Stainless Steel Development Association, Berlin Germany, (2000), 2.

44) H. Pariser: Met. Bull. Monthly, 369 (2001), September, 12.

45) T. Smith: Steel Times, 217 (2001), No. 5, 168.

46) R. Vondran: Steel Times, 227 (1999), No. 8, 303

47) C. P. Manning and R. J. Fruehan: JOM, 53 (2001), No. 10, 36.

48) H. Mueller: Steel Times Int., 26 (2002), No. 7-8, 46.

49) I. M. Pavlov: Theory of Rolling, Metallurgizdat, Moscow, (1950), 610 .

50) S. Buchanan: Met. Bull. Monthly, 363 (2001), March, 10.

51) J. Vaugh and D. Varcoe: SEAISI Quarterly, 30 (2001), No. 1, 46.

52) D. Senk, B. Engl, O. Siemon and G. Stebner: Steel Res., 70 (1999), No. 8-9, 368

53) T. Koyano, O. Terada, S. Uchida and M. Ishikawa: Proc of the 69th Steelmaking Conf., ISS, Warrendale, PA, (1986), 449.

54) M. Suzuki, H. Mizukami, T. Kitagawa, K. Kawakami, S. Uchida and Y. Komatsu: ISIJ Int., 31 (1991), 254.

55) M. M. Wolf: $B H M, 145$ (2000), No. 7, 270.

56) M. Suzuki, M. Suzuki and M. Nakada: ISIJ Int., 41 (2001), 670.

57) J. P. Birat, P. Blin, J. L. Jacquot, P. Riboud and B. Thomas: Rev. Metall., Cah. Inf. Tech., 86 (1989), No. 11, 919.

58) R. Fukase, A. Nomura and H. Kato: Japanese Patent JP3-128149, (1991).

59) J. C. Yoon, H. K. Moon, J. T. Duncombe and M. Rushforth: METEC Cong. 94 2nd European Continuous Casting Conf., 6th Int. Rolling Conf., Düsseldorf, Germany, (1994), 435.

60) B. Lindorfer, K. Schwaha, J. Spiess and G. Houze: Steel Times, 221 (1993), No. 7, 304.

61) T. Bagsarian: New Steel, 14 (1998), No. 12, 56

62) A. Ritt: New Steel, 16 (2000), No. 1, 20

63) J. Isenberg-O'Loughlin: Thirty-Three (33) Metal Producing, 36 (1998), No. 12, 20.

64) W. Blejde, R. Mahapatra and H. Fukase: Belton Memorial Symp. Proc., ISS, Warrendale, PA, (2000), 253 
65) H. Legrand, J. M. Damasse, M. Espenhahn, R. W. Simon and G. Stebner: THERMEC 97 Int. Conf. on Thermomechanical Processing of Steels and Other Materials, TMS, Warrendale, PA, (1997), 2.

66) M. Wolf: Steel Times Int. (Contibuous Casting Supplement), 19 (1994), No. 3, 4.

67) R. W. Simon, D. Senk, C. Mollers, H. Legrand, L. Vendeville and J. M. Damasse: Metall. Plant Technol. Int., 3 (1997), June, 78.

68) M. Wolf and W. Kurz: Proc. Int. Conf. on Solidifacation and Casting of Metals, The Metal Society, London, (1977), 287.

69) J. K. Brimacombe and I. V. Samarasekera: Iron Steelmaker, 21 (1994), No. 11, 29.

70) H. Fukase, W. J. Folder and W. Blejde: European Patent EP0627275, (1994)

71) Y. Fujita, H. Sato, T. Kitagawa, S. Nishioka, Y. Tsuchida and A. Ozeki: ISIJ Int., 29 (1989), 495.

72) P. Campbell and R. L. Wechsler: Heffernan Symposium, Ontario, Canada, (2001), 201.

73) P. Campbell, W. Blejde, R. Mahapatra and G. Gillen: 59th Electrical Furnace Conf. and 19th Process Technology Conf. Proc., ISS, Warrendale, PA, (2001), 727.

74) Anonymous: Steel Times, 228 (2000), No. 7, 256.

75) W. Blejde, R. Mahapatra and H. Fukase: METEC Cong. 99, VDEh, Düsseldorf, Germany, (1999), 176

76) O. Kubaschewski and B. E. Hopkins: Oxidation of Metals and Alloys, Butterworths, London, (1962), 319.

77) K. Brown and M. Assefpour: Steel Times, 221 (1993), No. 12, 524.

78) Thirty-Three (33) Metal Producing, 40 (2002), No. 1, 18.

79) T. Bagsarian: New Steel, 16 (2000), No. 12, 18

80) T. Kusakawa: Trans. Iron Steel Inst. Jpn., 26 (1986), B-123.

81) A. W. Cramb: Iron Steelmaker, 15 (1988), No. 7, 45

82) J. P. Birat and R. Steffen: Metall. Plant Technol. Int., 14 (1991), No. 3,44 .

83) J. K. Brimacombe and I. V. Samarasekera: Moden Steel Processing, 39th Canadian Chemical Engineering Conf., Hamilton, Ontario, Canada, (1989), 104.

84) J. P. Birat: Ironmaking Steelmaking, 14 (1987), No. $2,84$.

85) N. Jacobson, B. Hollinger and H. Fredriksson: Scand. J. Metall., 22 (1993), No. 2, 75.

86) M. Walter, G. Stebner, J. M. Damasse, P. Tolve and G. Hohenbichler: Steel Times Int., 25 (2001), No. 7, 33.

87) H.-U. Lindenberg, J. Henrion, K. Schwaha and G. Vespasiani: Stahl Eisen, 121 (2001), No. 12, 97

88) H. Legrand, U. Albrecht-Fruh and A. Flick: 85th Steelmaking Conf. Proc., ISS, Warrendale, PA, USA, (2002), 211

89) P. Tolve, R. Tonelli, R. Capotosti and G. Hohenbichler: THERMEC '97 Int. Conf. on Thermomechanical Processing of Steels and Other Materials, TMS, Warrendale, PA, (1997), 2.

90) A. Mascanzoni, J. M. Damasse and G. Hohenbichler: Steel Times Int., 25 (2001), No. 8, 45

91) H. Legrand and G. Martel: Steel Times, 226 (1998), No. 3, 104

92) J. M. Damasse, D. Themines and L. Vendeville: Rev. Métall., Cah. Inf. Tech., 97 (2000), No. 1, 43.

93) T. Furukawa: New Steel, 10 (1994), No. 10, 42

94) Steel Times, 227 (1999), No. 4, 128.

95) K. Yanagi, K. Yamamoto, H. Takatani, K. Sasaki, Y. Wakiyama, H. Takeuchi, H. Nakashima, S. Tanaka, M. Yamada and Y. Yamakami: METEC Cong. 94 2nd European Continuous Casting Conf. 6th Int. Rolling Conf., Düsseldorf, Germany, (1994), 423.

96) M. Yukumoto and H. Yamane: ISIJ Int., 35 (1995), No. 6, 778

97) S. Miyake, H. Yamane, M. Yukumoto and M. Ozawa: ISIJ Int., 31 (1991), 689

98) M. Mohri, K. Onishi, K. Yamada and N. Nishinae: THERMEC '97 Int. Conf. on Thermomechanical Processing of Steels and Other Materials, TMS, Warrendale, PA, (1997), 2.

99) D. Senk, G. L. Thompson, W. Bleck, P. Vicente, R. Kopp and R. Steffen: European Commission Technical Steel Research, EUR 19364 en, (2000), 132.

100) J. C. Grosjean, J. L. Lacquot, J. M. Damasse, H. Litterscheidt, D. Senk and W. Schmitz: Iron Steelmaker, 20 (1993), No. 8, 27.

101) H. Fiedler and M. Jurisch: Stahl Eisen, 111 (1991), No. 2, 79

102) M. Badowski, L. Hentschel, R. Kopp, W. Schmitz and D. Senk: Steel Res., 72 (2001), No. 11+12, 484 .

103) D. Senk, C. Schneider and R. Kopp: Rev. Métall., Cah. Inf. Tech.,
87 (1990), No. 4, 351

104) A. Girgensohn, A. R. Buchner and K. Tacke: Ironmaking Steelmaking, 27 (2000), No. 4, 317.

105) A. R. Buchner and J. W. Schmitz: Steel Res., 63 (1992), No. 1, 7

106) J. T. Choi, H. T. Chung, W. S. Kim and H. K. Moon: 83rd Steelmaking Conf., ISS, Warrendale, PA, (2000), 29.

107) H. K. Moon, C. M. Park, H. N. Cheong, C. G. Lee and T. Kang: Proc. Merton C. Flemings Symp. on Solidification and Materials Processing, TMS, Warrendale, PA, (2001), 507.

108) D.-Y. Choo, S. Lee, H.-K. Moon and T. Kang: Metall. Mater. Trans. $A, 32 \mathrm{~A}$ (2001), 2249.

109) A. L. Robson, J. Wilkinson and G. L. Thompson: METEC Cong. 94 2nd European Continuous Casting Conf., 6th Int. Rolling Conf., Düsseldorf, Germany, (1994), 443.

110) G. L. Thompson, S. R. Higson and P. J. Longdon: European Commission Technical Steel Research, EUR 18608 en, (1998), 49.

111) B. V. Molotilov, N. M. Zapuskalov and V. T. Timofeev: Steel USSR, 21 (1991), No. 12, 565.

112) N. Zapuskalov and M. Vereschagin: ISIJ Int., 38 (1998), 1107.

113) J. D. Hwang, H. J. Lin, W. S. Hwang and C. T. Hu: ISIJ Int., 35 (1995), 170.

114) H. Litterscheidt, R. Hammer, C. Schneider, R. W. Simon, D. Senk, R. Kopp and B. Hehl: Stahl Eisen, 111 (1991), No. 2, 61

115) M. S. Boichenko, I. M. Pavlov, A. A. Korolev, J. M. Bokshitskii and S. I. Irodov: Metall., (1940), No. 5, 11 .

116) N. M. Zapuskalov: Dissertation, TSNIICherMet, Moscow, (1992), 163.

117) K. Miyazawa, T. Choh and M. Inoue: J. Jpn. Inst. Met., 46 (1982), 944.

118) S. K. Ray, B. Mukhopadhyay and S. K. Bhattacharyya: ISIJ Int., 36 (1996), 611.

119) N. M. Zapuskalov, B. V. Molotilov, G. A. Srebrianskii and S. S. Golovanenko, Russian Patent N 1799674, (1993).

120) A. Jablonka, K. Harste and K. Schwerdtfeger: Steel Res., 62 (1991), No. 1, 24.

121) T. Kuster: New Steel, 12 (1996), No. 11, 68

122) B. R. Marple, S. Poudrette and F. G. Hamel: 75th Steelmaking Conf. Proc., ISS, Warrendale, PA, (1992), 353.

123) P. Fournier and F. Platon: Wear, 244 (2000), 118

124) K. Shibuya and M. Ozawa: ISIJ Int., 31 (1991), 661.

125) S. Hiraki, K. Nakajima, T. Murakami and T. Kanazawa: 75th Steelmaking Conf. Proc., ISS, Warrendale, PA, (1994), 397.

126) A. Buchner and H. Zimmermann: Steel Res., 73 (2002), No. 8, 327.

127) A. Sanz: Surface and Coating Technology, 146-147 (2001), 55.

128) L. Strezov and J. Herbertson: ISIJ Int., 38 (1998), 959.

129) M. Ha, J. Choi, S. Jeong, H. Moon, S. Lee and T. Kang: Metall. Mater. Trans. A, 33A (2002), 1487.

130) T. Mizoguchi, K. Miyazawa and Y. Ueshima: Tetsu-to-Hagané, 80 (1994), No. 1, 36

131) H. Yasunaka, K. Taniguchi, M. Kokita and T. Inoue: ISIJ Int., 35 (1995), 784.

132) S. Tanaka, I. Suichi, S. Ogawa, T. Furuya, K. Sasaki and K. Yanagi: 75th Steelmaking Conf. Proc., ISS, Warrendale, PA, (1991), 809

$133)$ R. P. Tavares and R. I. L. Guthrie: Can. Metall. Q., 37 (1998), No. 3-4, 241

134) European Patent EP0515075B1, (1992).

135) R. Tonelli, L. Sartini, R. Capotosti and A. Contaretti: METEC Cong. 94 2nd European Continuous Casting Conf., 6th Int. Rolling Conf., Düsseldorf, Germany, (1994), 20.

136) W. Blejde, R. Mahapatra and H. Fukase: Iron Steelmaker, 27 (2000), No. 4, 29

137) T. Tanaka: CAMP-ISIJ, 15 (2002), 208.

138) E. Luiten, Ph.D. Thesis, Utrecht University, Utrecht, (2001), 300

139) R. Wechsler: IISI-35 Conf., International Iron and Steel Institute, (2001) (from www.castrip.com)

140) T. Furukawa: Am. Met. Mark., 106 (1998), No. 217, November, 3.

141) Anonymous: Iron Steel Eng., 73 (1996), No. 4, 77.

142) R. McCulloch: Met. Bull. Monthly, 370 (2001), No. 10, 10.

143) Steel Times, 228 (2000), No. 10, 354.

144) Steel Times Int., 26 (2002), No. 4, 26.

145) Steel Times, 228 (2000), No. 11, 387.

146) C. S. Kuo: Minerals Yearbook, Vol. 3, International Minerals Statistics and Information, Korea, (1994), 713

147) J. Ball: Ironmaking Steelmaking, 27 (2000), No. 2, 91. 